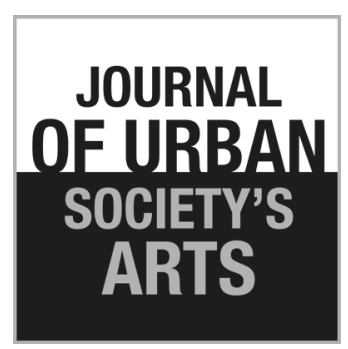

Volume 5 Nomor 1 , April 2018: 1-10

\section{Komik Wayang Anak Pandawa sebagai Media Pendidikan Karakter di Jaman Kekinian}

\author{
Wiekandini Dyah Pandanwangi dan Farida Nuryantiningsih \\ Dosen Jurusan Sastra Indonesia, Fakultas Ilmu Budaya \\ Universitas Jenderal Soedirman \\ Jln. Soeparno, Karangwangkal, Purwokerto \\ Tlp. 08121571986, E-mail: wiekepandanwangi@gmail.com
}

\begin{abstract}
ABSTRAK
Wayang telah melekat dan menjadi bagian hidup bangsa Indonesia khususnya Jawa. Dalam seni wayang, terdapat kearifan lokal yang bermanfaat untuk membangun karakter dan jati diri bangsa Indonesia yang tergambarkan melalui cerita dan watak para tokohnya. Pembangunan karakter yang berlandaskan kearifan lokal sebagai jati diri bangsa Indonesia bagi generasi muda sangatlah penting untuk mencetak anak bangsa yang cerdas, berkepribadian, dan berahklak mulia. Terlebih lagi jaman sekarang dimana anak-anak Indonesia sudah mulai luntur karakter aseli sebagai bangsa Indonesia karena tergerus globalisasi dan kecanggihan teknologi. Rasa hormat dan sopan santun kepada orang yang tua mulai pudar. Sifat yang individualistis lebih ditonjolkan sehingga terasa tidak humanis lagi kepada sesamanya. Itulah yang disebut sebagai istilah kids jaman now. Melihat hal tersebut, diperlukan media pendidikan karakter yang tepat untuk anak-anak. Media pendidikan karakter yang diilhami oleh budaya asli bangsa Indonesia seperti komik wayang anak Pandawa. Melalui media komik wayang anak Pandawa, akan dibangun karakter dalam diri anak dengan penanaman nilai-nilai kearifan lokal, yaitu mengenalkan cerita dan tokoh-tokoh wayang Pandawa. Semua tokoh dalam cerita wayang memiliki karakter yang bersumber dari kepribadian asli bangsa lndonesia. Filosofi kehidupan dalam cerita wayang dan karakter tokoh pewayangan perlu untuk dimaknai lebih mendalam karena esensinya sangat berguna bagi kehidupan, terlebih lagi untuk disampaikan pada generasi muda. Oleh sebab itu, komik wayang anak Pandawa diperlukan sebagai media untuk memahami filosofi kehidupan dalam cerita wayang dan karakter tokoh pewayangan sehingga mampu diserap dengan mudah oleh anak-anak.
\end{abstract}

Kata kunci: komik wayang; pandawa; pendidikan karakter; kekinian

\begin{abstract}
Wayang Pandawa Child Comics as Character Building Media in Today's Era. Wayang have been embodied and become part of the life of the Indonesian people, especially Java. In the art of wayang, there is a local wisdom that is useful to build the character and identity of the Indonesian people which is depicted through the stories and character of the characters. Character building based on local wisdom as the identity of the Indonesian people for the younger generation is very important to create intelligent, personality, and noble children of the nation. Even more so today, where Indonesian children have begun to wear off their original character as Indonesians because of the erosion of globalization and technological sophistication. Respect and courtesy to old people are fading. The individualistic nature is more highlighted so that it feels no longer humanistic to others. That is what is called the term kids today. Seeing this, the right character education media for children is needed. Media of character education inspired by the indigenous culture of the Indonesian people such as the Pandawa puppet comics. Through the Pandawa puppet comic media, characters will be built in the child by planting the values of local wisdom, namely introducing stories and figures of the Pandawa puppets. All characters in wayang stories have characters derived from the original personality of the Indonesian nation. The philosophy of life in wayang stories and puppet character needs to be interpreted more deeply because its essence is very
\end{abstract}


useful for life, moreover to be conveyed to the younger generation. Therefore, the Pandawa puppet comics are needed as a medium to understand the philosophy of life in wayang stories and puppet characters so that they can be absorbed easily by children.

Keywords: wayang comic; pandawa; character education; today's era

\section{Pendahuluan}

Wayang adalah sebuah wiracarita yang pada intinya mengisahkan kepahlawanan para tokoh yang berwatak baik menghadapi dan menumpas tokoh yang berwatak jahat. Kenyataan bahwa wayang yang telah melewati berbagai peristiwa sejarah, dari generasi ke generasi, menunjukkan betapa budaya pewayangan telah melekat dan menjadi bagian hidup bangsa Indonesia khususnya Jawa. Usia yang demikian panjang dan kenyataan bahwa hingga dewasa ini masih banyak orang yang menggemarinya menunjukkan betapa tinggi nilai dan berartinya wayang bagi kehidupan masyarakat. (Nurgiyantoro, 2011) menambahkan bahwa wayang yang telah melewati berbagai peristiwa sejarah, lintas generasi. Hal tersebut memperlihatkan budaya pewayangan telah melekat dalam kehidupan bangsa Indonesia khususnya Jawa. Siswanto (2003) mengatakan bahwa wayang merupakan bagian dari kebudayaan Jawa walaupun repertoirnya cerita Ramayana dan Mahabharata dari India. Meskipun begitu, wayang di Jawa dibuat dengan sikap kehidupan masyarakat Jawa sehingga pengaruh kejawaan dalam cerita wayang sangat kental. Oleh karena itu, wayang juga disebut identitas utama manusia Jawa.

Usia panjang dan kenyataan bahwa hingga saat ini masih banyak orang yang menggemari wayang menunjukkan betapa tinggi nilai dan berartinya wayang bagi kehidupan masyarakat. Wayang menjadi sumber inspirasi kehidupan masyarakat Jawa (Handoko, 2017). Menurut Handoko pula, dalam setiap pertunjukkan wayang menampilan tokoh-tokoh wayang dan peran yang harus dijalankannya. Setiap tokoh wayang memiliki karakter dan sifat yang jelas untuk dipahami sehingga dapat diketahui tokoh baik dan tokoh jahat. Lebih jauh lagi Marbangun (dalam Handoko, 2017) mengatakan bahwa tokoh wayang menampilkan berbagai karakter manusia dalam kehidupa nyata. Tokoh-tokoh tersebut menjadi sumber inspirasi yang juga sebagai cerminan jiwa. Oleh karena itu, wayang menjadi salah satu sumber panutan hidup.

Wayang merupakan sastra tradisional yang memenuhi kualifikasi karya masterpiece, karya sastra dan atau budaya adiluhung (Nurgiyantoro, 2011). Wayang bermula ketika nenek moyang bangsa Indonesia masih menganut animisme dan dinamisme. Pada zaman itu roh orang yang sudah meninggal yang dulunya berkuasa dipuja dan dimintai pertolongan. Untuk memuja roh nenek moyang itu, selain melakukan ritual tertentu mereka mewujudkannya dalam bentuk gambar dan patung. Roh nenek moyang yang dipuja itu disebut 'byang' atau 'dahyang'. Orang bisa berhubungan dengan para hyang ini melalui seorang medium yang disebut 'syaman'. Ritual pemujaan nenek moyang hyang dan syaman inilah yang merupakan asal mula pertunjukan wayang. Hyang menjadi wayang, ritual kepercayaan itu menjadi jalannya pentas dan syaman menjadi dalang. Bahasa yang digunakan adalah bahasa Jawa asli yang hingga sekarang masih dipakai. Jadi wayang dalam bentuknya yang masih sederhana adalah asli Indonesia (Senawangi, 2008: 29). Dalam seni wayang terdapat kearifan lokal yang bermanfaat untuk membangun karakter dan jatidiri bangsa Indonesia yang tergambarkan melalui watak tokoh dalam wayang. Menurut Mubah dalam Fajrie (2011: 305), jati diri bangsa sebagai nilai identitas masyarakat harus dibangun secara kokoh dan diinternalisasikan secara mendalam. Oleh karena itu, pembangunan karakter yang berlandaskan kearifan lokal sebagai jati diri bangsa Indonesia bagi generasi muda sangatlah penting.

Pembangunan karakter menjadi sebuah prioritas utama dalam tujuan pendidikan di lndonesia, untuk mencetak anak bangsa yang 
cerdas, berkepribadian dan berakhlak mulia. Selama ini pendidikan lebih menekankan pengembangan kemampuan intelektual akademis dan kurang memberi perhatian pada aspek yang sangat fundamental, yakni pengembangan karakter (watak), sedangkan karakter itu merupakan aspek yang sangat penting dalam penilaian kualitas sumber daya manusia. Seseorang dengan kemampuan intelektual yang tinggi dapat saja menjadi orang yang tidak berguna atau bahkan membahayakan masyarakat jika karakternya rendah. Oleh karena itu, pendidikan karakter seharusnya ditempatkan sebagai bagian penting dalam sistem pendidikan nasional. Berbagai kasus yang bertentangan dengan nilai-nilai moral seperti korupsi, kekerasan, kejahatan seksual, perusakan, perkelahian massa menunjukkan rendahnya karakter telah sedemikian marak dalam masyarakat. Lebih memprihatinkan lagi, perbuatan itu tidak sedikit melibatkan orang-orang yang terdidik. Dalam hubungannya dengan tujuan pendidikan, pendidikan karakter kepribadian seseorang harus dimulai sejak dini atau pada masa anak-anak (Swandayani, 2011). Alasan demikian karena masa kanak-kanak merupakan tahapan awal yang menentukan perkembangan masa dewasanya kelak.

Pendidikan karakter pada anak usia dini menjadi fondasi dasar dalam mengembangkan keterampilan sosial di masa yang akan datang. Terlebih lagi pembangunan karakter pada anak di jaman kekinian seperti saat ini. Pendidikan karakter yang kuat dan kokoh merupakan suatu hal yang harus ditanamkan sejak anak-anak agar generasi muda penerus bangsa memiliki pribadi yang unggul sehingga memperkuat bangsa menghadapi pengaruh negatif (Pandanwangi dan Nuryantiningsih, 2017).

Bangsa Indonesia memasuki era modern saat ini. Anak muda sering menyebutnya dengan istilah terkenal jaman kekinian atau jaman now. Modernisasi di Indonesia disebabkan oleh arus globalisasi yang melanda dunia dengan cepat. Kecanggihan informasi dan teknologi berkembang pesat memudahkan setiap orang untuk mengetahui apa saja yang sedang trend di belahan dunia manapun. Dengan kata lain, dunia ada dalam genggaman tangan. Modernisasi di Indonesia hampir di semua bidang kehidupan dan dirasakan oleh semua orang tak terkecuali anak-anak.

Modernisasi di berbagai bidang kehidupan dapat mendatangkan manfaat positif tapi sekaligus juga negatif. Manfaat positif dapat diambil bila kita memanfaatkan hasil modernisasi tersebut untuk segala sesuatu yang postif dan mendatangkan kebaikan. Sebaliknya, manfaat negatif akan kita rasakan apabila kita tidak dapat menyaring informasi yang bermanfaat dari kecanggihan teknologi dan informasi tersebut. Hal tersebutlah yang dialami anak-anak Indonesia saat ini. Pengaruh negatif modernisasi yang paling dapat dirasakan dari anakanak Indonesia adalah perubahan karakter. Anakanak Indonesia saat ini lebih menyukai hal-hal yang bersifat kekinian. Mereka bahkan bangga disebut sebagai kidsjaman now. Sutarno (2008) mengatakan bahwa kehidupan masyarakat Jawa pada abad ke21 dengan keseluruhan tahapan pembangunannya, ternyata membawa permasalahan dalam setiap aspek kehidupan. Masalah yang paling menonjol adalah perubahan sistem nilai. Padahal nilainilai baru yang muncul akibat globalisasi belum mencerminkan kehidupan bangsa Indonesia. Masyarakat Indonesia mengalami perubahan yang sangat cepat sehingga banyak yang kehilangan jati dirinya dan mengalami kebingungan. Oleh karena itu, menanamkan nilai-nilai tradisi sebagai budaya asli sangat perlu dilakukan.

Kondisi tersebut tak jarang memprihatinkan karena kekinian selalu identik dengan budaya import atau budaya yang berasal dari Barat. Dengan demikian, budaya aseli Indonesia atau budaya Timur yang kita miliki mulai luntur. Penyerapan budaya asing yang tanpa disaring menyebabkan karakter anak-anak Indonesia saat ini sangat memprihatinkan. Anak-anak Indonesia jaman kekinian lebih cenderung kurang humanis, tidak perduli, dan memiliki empati yang rendah terhadap sesamanya. Sebagai contoh, banyak terjadi perkelahian antarsiswa di sekolah, bullying dengan sesama teman, kebiasaan mencotek saat ujian, bangga saat melanggar peraturan sekolah, dan sering berkata bohong. Kondisi yang demikian dapat terjadi karena anak-anak sering mendapat tontonan, bacaan, dan informasi-informasi yang tidak sesuai usianya. Perlu diketahui bersama 
bahwa anak-anak adalah pribadi yang cepat sekali meniru. Mereka akan meniru apapun yang mereka dengar, lihat, dan alami di sekelilingnya dengan baik. Oleh karena itu, sangat wajar jika pengaruh-pengaruh negatif, mudah sekali masuk dalam kepribadian mereka. Berdasarkan kondisi tersebut, pendidikan karakter untuk anak-anak yang berakar pada budaya asli bangsa Indonesia sangat perlu dilakukan. Harapannya, anak-anak bangsa Indonesia akan mempunyai karakter unggul yang berakhlak mulia dan sesuai dengan kepribadian bangsa Indonesia. Pendidikan karakter yang demikian dapat dilakukan dengan mengambil wayang sebagai akar dasarnya. Pendidikan karakter yang berbasis budaya lokal seperti wayang memiliki beberapa tujuan strategis, yaitu pertama, anak-anak akan didekatkan dengan realitas kehidupan nyata yang sesunngguhnya. Kedua, budaya lokal dapat menjadi budaya tandingan bagi dampak globalisasi yang semakin parah. Ketiga, budaya lokal memiliki potensi dikembangkan kembali sehingga dapat direvitalisasi (Sutarso and Murtiyoso, 2008).

Wayang adalah salah satu budaya bangsa yang perlu dilestarikan dan diajarkan kepada anak sebagai generasi muda karena dalam cerita wayang terkandung banyak nasihat atau filosofi yang perlu disampaikan sebagai bekal pembentukan karakter yang baik. Purwanto and Yuliana (2016) mengatakan bahwa wayang merupakan salah satu media yang dapat dijadikan sebagai alat untuk menyampaikan pendidikan budi pekerti luhur bagi anak-anak. Hal demikian karena dalam pertunjukan wayang mengandung pesan moral yang baik apabila dihubungkan dengan kehidupan manusia. Upaya tersebut untuk menciptakan kehidupan yang tenteram dan damai. Wayang pun diibaratkan sebagai cerminan failosofi kehidupan manusia Jawa. Wayang juga merupakan ungkapan filosofi Jawa.

Banyak cerita yang memberikan pencontohan tentang kehidupan melalui karakter masing-masing tokohnya. Semua tokoh dalam cerita wayang memiliki karakter yang bersumber dari kepribadian bangsa lndonesia, sehingga sangat pas dijadikan media dalam pendidikan karakter bangsa. Oleh karena itu, salah satu cara membangun karakter dalam diri anak dengan menanamkan nilai-nilai kearifan lokal adalah dengan mengenalkan tokohtokoh wayang seperti Gatotkaca, Srikandi, Arjuna, dan sebagainya. Hal ini karena dalam tokoh-tokoh wayang tersebut, terkandung nilai-nilai luhur di antaranya sifat kasih sayang, pemaaf, sabar, bertanggung jawab, dan suka menolong. Dari sekian banyak tokoh wayang, tokoh wayang yang diambil dalam penelitian ini adalah tokoh wayang Pandawa. Hal ini karena selain tokoh Pandawa sudah dikenal baik oleh masyarakat sebagai tokoh protagonis, Pandawa banyak memiliki karakter yang pantas dijadikan contoh dalam sebuah pembelajaran karakter di sekolah. Sifat kasih sayang, pemaaf, sabar, bertanggung jawab, suka menolong dan sifat baik lainnya, semua ada pada diri tokoh Pandawa. Melalui media pembelajaran yang menarik dan berdasar pada kearifan lokal diharapkan karakter yang baik bisa dimiliki generasi muda Indonesia.

Untuk memahami cerita dan karakter wayang, bukanlah hal mudah karena penuh dengan filosofi dan norma-norma kehidupan yang perlu ditafsirkan. Diperlukan pembacaan mendalam untuk memahami kedua hal tersebut. Walaupun demikian, filosofi kehidupan dalam cerita wayang dan karakter tokoh pewayangan perlu dimaknai lebih mendalam karena esensinya sangat berguna bagi kehidupan, terlebih lagi untuk disampaikan pada generasi muda. Oleh sebab itu, diperlukan media penyampaian yang mempermudah generasi muda khususnya anak usia sekolah dasar untuk memahami filosofi kehidupan dalam cerita wayang dan karakter tokoh pewayangan. Media tersebut berwujud komik wayang. komik dapat dimasukkan sebagai bacaan anak. (Swandayani, 2011) menekankan bahwa bacaan anak dapat menjadi media eksplorasi imajinasi anak. Dengan membaca, anak diharapkan mampu berimajinasi sehingga merangsang daya analisis dan kreativitasnya dalam menyelesaikan permasalahan.

\section{Nilai Filosofi dalam Cerita Wayang Pandawa}

Wayang pada dasarnya merupakan gambaran kehidupan manusia. Banyak sekali tokoh dan peristiwa di dalam dunia pewayangan yang mirip dengan kehidupan nyata. Dengan kata lain, tokoh 
wayang mewakili sosok pribadi manusia hidup sedangkan cerita wayang mewakili kehidupan nyata. Cerita dan tokoh wayang Pandawa diambil dalam penelitian ini karena cerita dan tokoh Pandawa sudah dikenal baik oleh masyarakat sebagai tokoh protagonis, Cerita wayang Pandawa dan karakter para tokohnya mengandung filosofi dan norma-norma kehidupan yang tepat dijadikan pendidikan karakter bagi anak. Tokoh Pandawa memiliki karakter yang pantas dijadikan contoh dalam sebuah pembelajaran karakter di sekolah. Sifat kasih sayang, pemaaf, sabar, bertanggung jawab, suka menolong, jujur dan sifat baik lainnya, semua ada pada diri tokoh Pandawa. Melalui media pembelajaran yang menarik dan berdasar pada kearifan lokal, diharapkan filosofi kehidupan dan karakter yang baik bisa dimiliki generasi muda Indonesia.

Pandawa adalah sebutan bagi kelima orang putra Pandu Dewanata (Senawangi, 2008: 981982). Ayah Pandawa, yakni Pandu Dewanta adalah raja Astina. Akan tetapi, Raja Pandu mati muda saat Pandawa masih anak-anak sehingga untuk sementara Dresarastra yang juga paman Pandawa naik takhta. Rencananya kelak, bilamana para Pandawa telah dewasa, takhta Astina diserahkan kembali pada Pandawa. Akan tetapi, hal tersebut tidak terjadi karena istri Drestarastra dan anakanaknya (Kurawa) memiliki sifat dengki sehingga tidak rela jika takhta Astina dikembalikan pada putra Pandu. Peristiwa tersebut pemicu terjadinya perang Baratayuda antara Pandawa dan Kurawa.

Sebagai gambaran yang mewakili karakter manusia di dunia, wayang juga tidak lepas dengan nafsu, baik nafsu baik maupun nafsu jahat. Dalam cerita Pandawa, nafsu baik diwakili oleh Pandawa dan nafsu jahat oleh Kurawa. Nafsu baik dan jahat tersebut bertempur dalam perang Baratayuda. Perang Baratayuda sendiri adalah adalah perangnya Pandawa yang tokoh baik dengan Kurawa yang tokoh jahat yang sesungguhnya Pandawa dan Kurawa masih saudara sepupu. Menurut Senawangi (2008: 228), perang Baratayuda bukan hanya perang memperebutkan takhta kerajaan Astina saja, tetapi juga merupakan perang antara yang baik dan yang batil. Antara kejujuran dan kebenaran melawan keserakahan dan kejahatan.
Perang Baratayuda tidak boleh dihindarkan seperti yang diuraikan Bagawat Gita kepada Arjuna (Senawangi, 2008: 228). Hal ini karena salah satu kewajiban seorang kesatria adalah menumpas kejahatan dan ketidakadilan walaupun untuk itu ia harus berhadapan dengan saudara atau bahkan gurunya sendiri. Dalam perang Baratayuda terkandung simbol bahwa akan terajdi sepanjang masa dimana nafsu baik akan melawan nafsu buruk, tokoh baik akan selalu bertentangan dengan tokoh jahat. Selain itu, tidak selamanya hubungan kekeluargaan akan selalu seiring sejalan dalam satu pemikiran. Bahkan tidak jarang sering bertentangan.

Filosofi lain yang dapat diambil dari cerita Pandawa adalah putaran kehidupan manusia dimulai dari awal hingga akhir. Intinya manusia dimulai dari lahir kemudian mengalami perjalanan hidup terus mati. Hal tersebut seperti dialami Pandawa yang dimulai dari lahir terus mengalami perjalanan hidup, peristiwa-peristiwa penting yang terjadi dalam kehidupannya. Dari mulai difitnah, diasingkan, dipermalukan, melawan kejahatan dan kemungkaran sampai pada taraf sadar dan mulai legowo meninggalkan semua gemerlap kehidupan dan takhta kekuasaan untuk bersiap meninggalkan dunia fana dengan kematian yang abadi.

\section{Karakter Tokoh Pandawa}

Yudhistira atau yang juga dikenal sebagai Puntadewa adalah kakak tertua dari Pandawa Lima. Dia juga pemimpin Pandawa. Pada tokoh Yudhistira, memiliki simbol keyakinan mendalam untuk mengalahkan kejahatan. Karakter Yudhistira dalam cerita pewayangan meliputi, sifatnya sangat bijaksana dan tidak memiliki musuh. Memiliki moral yang sangat tinggi, suka mema'afkan serta suka mengampuni musuh yang sudah menyerah. Yudhistira adalah lambang atau sosok yang suci. Yudhistira benar-benar memiliki sikap ksatria sehingga disebut ksatria dari Amarta. Yudhistira juga lambang kejujuran karena dia tidak pernah berbohong selama hidupnya. Dari Yudhistira, anak-anak dapat belajar bahwa jadi pemimpin itu harus jujur. Dengan kejujuran, semua masalah dapat diatasi. 
Bima atau juga dikenal dengan Werkudoro digambarkan memiliki sosok yang bertubuh tinggi besar seperti raksasa dan wajah yang garang tetapi selalu menunduk yang dapat diartikan bersikap santun, andap asor, lembah manah. Bima dengan nama kecilnya Sena merupakan putra kedua Pandu dengan Dewi Kunti. Ia merupakan penjelmaan dari Dewa Bayu sehingga memiliki nama julukan Bayusutha. Bima sangat kuat, lengannya panjang, tubuhnya tinggi, dan berwajah paling sangar di antara saudara-saudaranya. Meskipun demikian, ia memiliki hati yang baik. Pandai memainkan senjata gada. Senjata gadanya bernama Rujakpala. Bima juga dijuluki Werkudara. Dalam pewayangan Jawa, Bima memiliki anak yaitu Gatotkaca, Antareja dan Antasena.

Bila sedang melakukan sesuatu, Bima tidak bisa diganggu sampai ia selesai. Ia juga mempunyai kekuatan yang disebut sebagai Aji Pancanaka yang berarti lima kekuatan. Dalam pewayangan, Bima juga diibaratkan sebagai jari telunjuk. Ia memiliki perawakan raksasa dengan hati yang lurus seperti jari telunjuk dan galak untuk mengingatkan sesuatu. Hal ini seperti budaya masyarakat kita, yang jika sedang marah akan menggunakan jari telunjuk yang mengacung untuk mengingatkan kesalahan kepada orang lain.

Dalam dunia pewayangan, Bima memililki sifat dan perwatakan; gagah berani, teguh, kuat, tabah, patuh dan jujur. Ia juga memiliki sifat kasar dan menakutkan bagi musuh, walaupun sebenarnya hatinya lembut, setia pada satu sikap, tidak suka berbasa basi dan tak pernah bersikap mendua serta tidak pernah menjilat ludahnya sendiri. Bima adalah simbol ketegasan, keberanian dan keadilan, serta kejujuran dalam menghadapi masalah melawan kejahatan. Bagi Bima, siapa yang salah harus dihukum. Bima pun selalu menepati janji yang ducapkannya. Dari Bima, anak-anak dapat belajar ketegasan dan keadilan dalam membela kebenaran serta berpegang teguh pada janji.

Arjuna yang juga dikenal dengan nama Janaka adalah seorang yang suka bertapa. Arjuna dengan nama kecilnya Permadi. Arjuna merupakan putra bungsu Dewi Kunti dengan Pandu. Ia merupakan penjelmaan dari Dewa Indra, Sang Dewa perang.
Arjuna merupakan ksatria rupawan tanpa tanding. Ia adalah ksatria cerdik dan gemar berkelana, gemar bertapa dan berguru menuntut ilmu. Arjuna memiliki kemahiran dalam ilmu memanah dan dianggap sebagai ksatria. Kemahirannya dalam ilmu peperangan menjadikannya sebagai tumpuan para Pandawa agar mampu memperoleh kemenangan saat pertempuran besar melawan Kurawa. Oleh sebab itu, Arjuna dijuluki ksatria tanpa tanding.

Arjuna memimpin kerajaan di Madukara. Ia berjiwa teguh. Dalam cerita pewayangan, dengan pertapaannya ini, Arjuna menjalankan laku perihatin. Oleh sebab itu, Arjuna akan memiliki jiwa yang kuat dan tenang untuk menghadapi segala tantangan dan cobaan hidup. Arjuna memiliki sifat perwatakan cerdik pandai, pendiam, lemah lembut budinya,teliti, sopansantun, berani dan suka melindungi yang lemah. Kehebatan Arjuna yang tanpa tanding itu tidak diperoleh secara instan. Sebabnya, Arjuna sosok yang tekun belajar, melewati proses yang keras dengan kegigihan. Dari Arjuna, kita bisa belajar keteguhan dan kekuatannya dalam menempuh proses pendidikan keilmuan atau ngangsu kawruh sehingga Arjuna bisa menjadi ksatria tanpa tanding.

Nakula adalah kakak tua dari saudara kembarnya, Sadewa. Nakula dengan nama kecilnya Pinten merupakan salah satu putera kembar pasangan Dewi Madrim dan Pandu. Ia merupakan penjelmaan Dewa kembar bernama Aswin, Sang Dewa pengobatan. Nakula pandai memainkan senjata pedang. Nakula merupakan pria yang paling tampan di dunia dan merupakan seorang ksatria berpedang yang tangguh. Ia digambarkan sebagai kesatria pandawa yang rajin dan giat bekerja. Penampilannya juga tidak sembarangan dengan pakaian rapi dan bagus namun tetap dermawan. Nakula memilki perwatakan jujur, setia, taat pada orang tua dan tahu membalas budi serta dapat menjaga rahasia. Dari Nakula, anak-anak dapat mengambil sikap untuk menjaga rahasia yang sudah dipercayakan kepadanya, memiliki rasa sayang, dan belas kasih pada sesama manusia.

Sadewa yang merupakan adik termuda dalam Pandawa Lima memiliki sifat yang mirip dengan kakak kembarnya, Nakula. Sadewa adalah orang yang sangat rajin dan bijaksana. Sadewa 
juga merupakan seseorang yang ahli dalam ilmu astronomi. Ia dalam berpenampilan juga rapi dan bagus sehingga sedap dipandang mata. Sifat yang selalu memberi juga tampak dari dirinya persis seperti Nakula. Sadewa digambarkan sebagai orang yang mampu membawa kestabilan dan kebersihan. Di dalam salah satu kisah pewayangan, kemampuan Sadewa ini diceritakan sampai mampu membersihkan Bethari Durga untuk kembali ke wujud awal beliau, Dewi Uma. Hal ini menggambarkan Sadewa sebagai anggota Pandawa termuda yang mampu membersihkan sampai ke sela-sela terkecil apapun. Sadewa digambarkan memilki sifat bijaksana dan pintar. Sadewa mampu melihat masa depan yang belum terjadi (ngerti sakdurunge winarah). Dari Sadewa, anak-anak dapat mengambill sikap untuk selalu bijaksana dalam menghadapi kehidupan serta menyongsong masa depan dengan optimis.

\section{Komik Wayang Pandawa sebagai Media Pendidikan Karakter Anak}

Perkembangan teknologi komunikasi menjadi bagian. yang tidak terpisahkan dari manusia modern (Sigit and Surahman, 2016). Hampir setiap sendi kehidupan baik itu sosial, ekonomi, politik sampai seni budaya menggunakan teknologi. Kehadiran teknologi di zaman globalisasi tidak dapat dilepaskan keberadaannya. Oleh karena itu, menyampaikan wayang pada anak-anak zaman kini dapat menggunakan teknologi tersebut, yaitu dengan pembuatan komik. Sejalan dengan Surahman, Saptodewo (2015) berpendapat bahwa cerita wayang, sebaiknya disampaikan dengan gaya dan media yang modern untuk mengikuti perkembangan zaman. Namun demikian, tidak menghilangkan atau melupakan apa itu wayang. Harapannya agar budaya kita tetap hidup. Budaya tersebut tumbuh dan berkembang mengikuti zaman. Supaya menarik minat generasi muda untuk melestarikannya, maka diperlukan inovasi baru untuk menyampaikan budaya tersebut. Menurut Riyanto (2011), wayang merupakan produk kreatif yang mempunyai banyak jenis ragam cerita dan penampilan visual bonekanya. Hal demikian disebut oleh Unesco sebagai karya agung manusia. Dengan kata lain, wayang tidak berarti sempit hanya terbatas pada seni pertunjukan wayang kulit purwa atau pertunjukan wayang wong (orang) purwa saja. Oleh karena itu, wayang menjadi sebuah komik untuk anak bukalan suatu hal yang melanggar norma-norma pewayangan.

Heru Dwi Waluyanto (2005) mengatakan bahwa dalam suatu pembelajaran siswa harus menikmati proses belajar. Oleh karena itu, pentingnya media yang berpotensi untuk meningkatkan kemampuan berpikir kreatif. Media tersebut harus kreatif dan menarik minat baca anak. Menurut Pranata dalam (Heru Dwi Waluyanto, 2005) seseorang akan belajar secara maksimal jika berinteraksi dengan stimulus yang cocok dengan gaya belajarnya. Salah satu caranya adalah memanfaatkan media visual. Materi atau media yang bersifat visual tersebut dapat berupa peta (maps), diagram, poster, dan komik. Komik sebagai media pembelajaran merupakan salah satu media yang dipandang efektif untuk pembelajran dan pengembangan kreativitas anak-anak. Komik adalah cerita bergambar untuk menyampaikan informasi tertentu. Komik lebih dari sekedar cerita bergambar yang ringan dan menghibur. Komik merupakan media komunikasi visual yang mempunyai kekuatan untuk menyampaikan informasi secara popular dan mudah dipahami. Hal tersebut karena komik memadukan kekuatan gambar dan tulisan, yang dirangkai dalam suatu alur cerita gambar membuat informasi lebih mudah diserap. Teks dalam balon-baloan gambar membuat komik lebih mudah dipahami anak dan alurnya juga mudah diingat.

Seto Mulyadi (Soedarso, 2015) menambahkan bahwa komik dapat mejadi media visualisasi imajinasi anak yang belum bisa membaca. Visualisasi anak sangat penting karena imajinasi mereka terbatas. Lebih jauh lagi Soedarso (2015) mengatakan bahwa komik saat ini dapat menjadi salah satu media komunikasi yang berperan memberikan informasi maupun pendidikan. Komik dapat sebagai media hiburan, media pendidikan, maupun media penyampai informasi lain yang menyampaikan sebuah pesan. Komik wayang merupakan genre endemik dalam konstelasi komik Indonesia (Mataram, 2015). R.A. Kosasih merupakan komikus legendaris yang mengawali 
genre tersebut. kemunculan komik wayang di Indonesia menyebabkan Indonesia memiliki genre sendiri yang tidak ditemukan pada dunia komik di negara lain. Komik wayang cukup berperan dalam kebudayaan Indonesia. salah satunya adalah membantu membantu dunia pendidikan di Indonesia dengan komik wayang. Dengan menggunakan bahasa Indonesia, komik wayang tidak hanya dibaca oleh orang Jawa atau Sunda saja, tetapi juga dari berbagai suku bangsa lain di Indonesia.

Komik wayang dipilih sebagai media penyampaian pendidikan karakter yang bersumber dari cerita dan tokoh wayang Pandawa. Komik sebagai bagian dari media cetak, dapat dikembangkan sebagai alternatif media pembelajaran (Saputro and Soeharto, 2015). Berkaitan dengan pendapat tersebut, Maharsi (Saputro and Soeharto, 2015) mengatakan bahwa komik berperan memberikan informasi yang mendidik, Daryanto dalam (Saputro and Soeharto, 2015) tentang kelebihan komik sebagai media pembelajaran. Kelebihan komik sebagai media pembelajaran adalah komik mengandung unsur visual dan cerita yang kuat. Ekspresi yang divisualisasikan membuat pembaca terlebih anakanak terlibat secara emosional sehingga membuat pembaca untuk terus membacanya hingga selesai. Karena itu, komik dapat meningkatkan baca siswa. Komik sebagai media pembelajaran dapat secara efektif mentransfer nilai-nilai pembelajaran yang ingin disampaikan kepada pembacanya. Komik dapat memotivasi pembaca terutama anak untuk mengembangkan imajinasi serta memberikan inspirasi terhadap apa yang sudah dibacanya. Lebih lanjut, Saputro and Soeharto (2015) menjelaskan bahwa komik itu unik karena tampil dengan deretan gambar, panel-panel dengan sedikit tulisan tangan yang ditempatkan dalam balon-balon teks. Gambar-gambar komik itu sendiri pada umumnya sudah "berbicara", dan dibuat menjadi deretan gambar yang menampilkan suatu alur cerita. Komik yang memiliki tema tertentu sebagai media pembelajaran akan menyebabkan pembelajaran yang ingin disampaikan efektif.

Menekankan penjelasan di atas, hasil penelitian (Pandanwangi, dkk, 2015) menyebutkan bahwa komik merupakan salah satu media yang menarik untuk menyampaikan pembelajaran. Hasil penelitian menunjukkan komik dapat membantu siswa untuk memahami materi yang abstrak dan sulit dipahami oleh pemikiran anak-anak.dalam penelitian ini, Pandawangi mengangkat pendidikan antikorupsi dalam komiknya. Melalui komik juga, anak tidak akan terpaksa belajar. Mereka lebih merasa seperti membaca sebuah cerita bergambar. Komik dengan cerita lucu dan karakter gambar yang berwarna serta sesuai dengan usia anakanak membuat anak-anak mudah memahami materi yang disampaikan. Mereka tidak sadar jika sebetulnya sedang belajar.

Pendapat senada disampaikan oleh Nuryantiningsih, dkk (2016) dalam penelitiannya. Menurut penelitian Nuryantiningsih, anak-anak, siswa sekolah dasar lebih mudah memahami mata pelajaran bahasa Jawa melalui komik bahasa Jawa yang diberikan. Para siswa juga lebih tertarik belajar karena disajikan materi yang kreatif dan menarik minat baca mereka. Mata pelajaran bahasa Jawa yang selamat ini sulit dipelajari terasa lebih mudah dengan adanya komik bahasa Jawa.

Komik adalah cerita yang bertekanan pada gerak dan tindakan yang ditampilkan lewat urutan gambar yang dibuat secara khas dengan panduan kata-kata (Feanz\&Meier dalam Nurgiyantoro, 2005: 410). Hampir seluruh teks komik tersusun dari hubungan antar gambar (lambang visual) dan kata-kata (lambang verbal). Cerita dibangun dan dikembangkan lewat gambar dan kata. Katakata biasanya ditampilkan dalam gelembunggelembung atau balon-balon yang dikreasikan sedemikian rupa sehingga serasi dengan gambargambar. Balon-balon teks dapat berupa ujaran atau pikiran dan perasaan tokoh (teks gelembung bicara dan gelembung pikiran), namun juga dapat berisi deskripsi singkat tentang sesuatu (Nurgiyantoro, 2005: 410).

Komik dapat digunakan sebagai media pembelajaran yang unik karena menggabungkan teks dan gambar dalam bentuk yang kreatif (Pamuji, 2014). Komik juga merupakan media yang sanggup menarik perhatian semua orang dari segala usia karena memiliki kelebihan yaitu mudah dipahami. Gambar yang sederhana ditambah kata- 
kata dalam bahasa sehari-hari membuat komik dapat dibaca oleh semua orang. Melalui komik, pengajar dapat mengkomunikasikan secara visual karena komik berpotensi sebagai sarana yang lebih informatif sehingga materi dapat disampaikan dengan lebih mudah dan menarik. Menurut Sudjana dan Rivai (Pamuji, 2014), komik dapat diterapkan untuk menyampaikan pesan dalam berbagai ilmu pengetahuan, dapat membangkinkan minat, mengembangkan perbendaharaan kata-kata dan keterampilan membaca, serta meningkatkan minat baca siswa. Dengan demikian, komik wayang Pandawa dirasa tepat untuk menyampaikan filosofi kehidupan dalam cerita wayang Pandawa dan karakter tokoh wayang Pandawa sebagai media pendidikan karakter untuk anak usia sekolah dasar.

\section{Simpulan}

Wayang adalah salah satu budaya bangsa yang perlu dilestarikan dan diajarkan kepada generasi muda karena dalam cerita wayang terkandung banyak nasihat atau filosofi yang perlu disampaikan sebagai bekal pembentukan karakter yang baik. Semua tokoh dalam cerita wayang memiliki karakter yang bersumber dari kepribadian bangsa Indonesia, sehingga sangat pas dijadikan media dalam pendidikan karakter bangsa. Oleh karena itu, salah satu cara membangun karakter dalam diri anak dengan menanamkan nilai-nilai kearifan lokal adalah dengan mengenalkan cerita dan tokohtokoh wayang seperti tokoh Pandawa.

Untuk memahami cerita dan karakter wayang, diperlukan media penyampaian yang mempermudah generasi muda khususnya anak usia sekolah dasar untuk memahami filosofi kehidupan dalam cerita wayang dan karakter tokoh pewayangan. Media tersebut berwujud komik wayang. Melalui komik, wayang Pandawa, pengajar dapat mengkomunikasikan secara visual karena komik berpotensi sebagai sarana yang lebih informatif sehingga materi dapat disampaikan dengan lebih mudah dan menarik. Dengan demikian, pendidikan karakter yang bersumber dari cerita dan karakter tokoh wayang Pandawa dapat dipahami dengan baik oleh anak-anak.

\section{Kepustakaan}

Fajrie, Nur. "Media Pertunjukan Wayang untuk Menumbuhkan karakter Anak Bangsa". PGSD-FKIP- Universitas Muria Kudus. http://publikasiilmiah.ums.ac.id.

Handoko, Antonius, Subandi. 2017. "Peran Identifikasi Tokoh Wayang dalam Pembentukan Identitas Diri”. Jurnal Psikologi, Volume 44, Nomer 2, 2017: 97-106. https://journal.ugm. ac.id/jpsi/article/view/22793/17393. Diakses, 13 Oktober 2018.

Heru Dwi Waluyanto (2005) 'Komik Sebagai Media Komunikasi Visual Pembelajaran', Jurnal Nirmana, 7(1), pp. 45-55. doi: 10.9744/nirmana.7.1. Surabaya: Universitas Kristen Petra. http://ced.petra.ac.id/index. $\mathrm{php} / \mathrm{dkv} / \mathrm{article} / \mathrm{view} / 16441$.

Mataram, S. (2015) 'BAHASA RUPA KOMIK WAYANG KARYA R . A . KOSASIH’, Jurnal Seni Budaya Gelar. Vol.13, No.1. pp. 13-21. ISI Surakarta. https://jurnal.isi-ska.ac.id/ index.php/gelar/article/view/1537

Nurgiyantoro, Burhan. 2005. Sastra Anak. Yogyakarta: Gadjah Mada University Press.

Nurgiyantoro, B. (2011) 'Wayang dan pengembangan karakter bangsa', Wayang Dan Pengembangan Karakter Bangsa, (1), pp. 1-17. doi: 10.21831/jpk.v1i1.1314.

Nuryantiningsih, Farida, dkk. 2016. "Peningkatan Budi pekerti anak Sekolah dasar melalui Pemakaian Undhausuk Bahasa Jawa”. Purwokerto: LPPM Unsoed

Pamuji, Muhammad Bagus. 2014. "Pengembangan komik sebagai Media Pembelajaran Biologi pada Materi Sistem Saraf Manusia untuk SMP/MTS Kelas IX Semester Ganjil. www. diglib.uin.suka.ac.id. Diakses, 2 Juli 2017.

Pandanwangi. Wiekandini. 2015. "Model Pendidikan Karakter Berlandasakan Falsafah Jawa sebagai Pencegahan Korupsi sejak Usia Dini”. Purwokerto: LPPM Unsoed

Pandanwangi, W. D. and Nuryantiningsih, F. (2017) 'Animasi Kartun Bertema Falsafah Jawa Sebagai Pendidikan Karakter Bagi Anak Usia Dini', Jurnal Rekam, 13(1), pp. 21-28. Yogyakarta: Fakultas Seni Media Rekam, ISI 
Yogyakarta. http://journal.isi.ac.id/index. php/rekam/article/view/1644. Diakses, 13 Oktober 2018.

Purwanto, E. and Yuliana, M. E. (2016) 'Penerapan animasi pertunjukan wayang sebagai media pendidikan budi perkerti dan memperkenalkan budaya bangsa kepada anak usia dini', Jurnal Sainstech, 1(6), pp. 21-31. http://www.poltekindonusa.ac.id/wpcontent/uploads/2017/01/Artikel-4_JurnalSainstech_Vol-1-Nomer-6-Desember-2016_ Eko-Purwanto.pdf.

Riyanto, B. (2011) 'Wayang Purwa dan Tantangan Teknologi Media Baru', Jurnal Nirmana, 13, pp. 5-11. doi: 10.9744/nirmana.13.1.5-11. http://nirmana.petra.ac.id/index.php/dkv/ article/view/18411/18230

Saptodewo, F. (2015) 'Mempopulerkan Cerita Pewayangan Di Kalangan Generasi Muda Melalui Motion Comic', Jurnal Desain, 2(3), pp. 145-156. http://journal.lppmunindra. ac.id/index.php/Jurnal_Desain/article/ viewFile/580/546

Saputro, H. B. and Soeharto (2015) 'Pengembangan Media Komik Berbasis Pendidikan Karakter Pada Pembelajaran Tematik-Integratif Kelas Iv Sd', Jurnal Prima Edukasia, 3(1), pp. 61-72. doi: http://dx.doi.org/10.21831/jpe. v3i1.4065. https://journal.uny.ac.id/index. php/jpe/article/view/4065/3520

Senawangi. 2008. Ensiklopedia wayang Indonesia. Jakarta: Sakanindo Printama.

Sigit and Surahman (2016) 'Determinisme
Teknologi Komunikasi Dan Globalisasi Media Terhadap Seni Budaya Indonesia', Jurnal Rekam, 12(1), pp. 31-41. ISI Yogyakarta. http://journal.isi.ac.id/index.php/rekam/ article/view/1385

Siswanto, J. (2003) "Metafisikan Wayang, Simbol Ontologis Wayang Sebagai Simbol Kehidupan”, Jurnal Filsafat, 13(1). Available at: https://journal.ugm.ac.id/wisdom/article/ view/31275/18896.

Soedarso, N. (2015) 'Komik: Karya Sastra Bergambar', Humaniora, 6(4), pp. 496-506. Universitas Bina Nusantara. http://journal. binus.ac.id/index.php/Humaniora/article/ view/3378

Sutarno. 2008. "Pertunjukan Wayang dalam Era Global”. Jurnal Resital, Vol.9, No. 2, 2008. Yogyakarta: ISI Yogyakarta. http://journal.isi. ac.id/index.php/resital/article/view/463/57

Sutarso, J. and Murtiyoso, B. (2008) 'Wayang Sebagai Sumber dan Materi Pembelajaran Pendidikan Budi Pekerti Berbasis Budaya Lokal', Jurnal Penelitian Humaniora, 9(1), pp. 1-12. Surakarta: Universitas Muhammadiyah Surakarta. https://publikasiilmiah.ums.ac.id/ xmlui/handle/11617/586

Swandayani, D. (2011) 'Sastra sebagai Dasar Pendidikan Karakter Bangsa', (November). Makalah dalam Seminar Nasional "Pengajaran Bahasa Asing dan Pendidikan Karakter", Jurusan Pendidikan Bahasa Jerman, Fakultas Bahasa dan Seni, UNY pada tanggal 10 November 2011. 